\title{
Exploring the chemodiversity of tropical microalgae for the discovery of natural antifouling compounds
}

\author{
Réveillon Damien ${ }^{1,2}$, Tunin-Ley Alina ${ }^{3}$, Grondin Isabelle ${ }^{4}$, Othmani Ahlem ${ }^{1}$, Zubia Mayalen ${ }^{5}$,
} Bunet Robert ${ }^{6}$, Turquet Jean ${ }^{3}$, Culioli Gérald ${ }^{1,{ }^{*}}$, Briand Jean-François ${ }^{1, *}$

\author{
${ }^{1}$ MAPIEM EA 4323, Université de Toulon, Toulon, France \\ ${ }^{2}$ Laboratoire Phycotoxines, Ifremer, Nantes, France \\ ${ }^{3}$ Hydrô Réunion, CBEM c/o CYROI, Sainte Clotilde, La Réunion, France \\ ${ }^{4}$ Laboratoire de Chimie des Substances Naturelles et des Sciences des Aliments (LCSNSA), Université \\ de La Réunion, Saint-Denis, France \\ ${ }^{5}$ Université de Polynésie Française, UMR-EIO, LabEx-CORAIL, BP 6570, 98702 Faa'a, Tahiti, French \\ Polynesia \\ ${ }^{6}$ Institut Océanographique Paul Ricard, lle des Embiez, Six-Fours-les-Plages, France \\ * Corresponding author : Gérald Culioli, email address : culioli@univ-tln.fr ; Jean-François Briand, email \\ address : briand@univ-tln.fr
}

\begin{abstract}
:
Marine microalgae and cyanobacteria have largely been studied for their biotechnological potential and proved their ability to produce a wide array of bioactive molecules. We investigated the antifouling potential of unexplored benthic tropical microalgae using anti-adhesion and toxicity bioassays against two major micro- and ma crobiofoulers, namely bacteria and barnacles. Fifty strains belonging to six phyla [Cyanobacteria, Miozoa (Dinoflagellata), Bacillariophyta, Cryptophyta, Rhodophyta and Haptophyta] were isolated from southwestern Islands of the Indian Ocean. They were chosen in order to represent as much as possible the huge biodiversity of such a rich tropical ecosystem. The associated chemodiversity was highlighted by both NMR- and LC-MS-based metabolomics. The screening of 84 algal fractions revealed that the anti-adhesion activity was concentrated in methanolic ones (i.e. $93 \%$ of all active fractions). Our results confirmed that microalgae constitute a promising source of natural antimicrofoulants as 17 out of the 30 active fractions showed high or very high capacity to inhibit the adhesion of three biofilm-forming marine bacteria. Dinoflagellate-derived fractions were the most active, both in terms of number and intensity. However, dinoflagellates were also more toxic and may not be suitable as a source of environmentally friendly antifouling compounds, in contrast to diatoms, e.g. Navicula mollis. The latter and two dinoflagellates of the genus Amphidinium also had interesting antisettlement activities while being moderately toxic to barnacle larvae. Our approach, combining the bioprospecting of a large number of tropical microalgae for their anti-settlement potential and metabolomics analyses, constituted a first step towards the discovery of alternative ecofriendly antifoulants.
\end{abstract}

Keywords : Microalgae, Antifouling, Bioassay, Chemodiversity, Bioprospecting, Metabolomics 


\section{Introduction}

Biofouling is a natural multistep process leading to the rapid colonization of any underwater surface by a multitude of micro- (e.g. bacteria, diatoms, fungi) and macrofoulers (e.g. macroalgae, barnacles) (Abarzua and Jakubowski 1995). The formation of biofilms on man-made structures is a global major issue causing huge economic impacts for marine industries (Yebra et al. 2004; Schultz et al. 2011). Efficient organotin-based antifouling (AF) paints have been banned since 2008 due to their high toxicity and adverse environmental effects (Dafforn et al. 2011). They were mainly replaced by coatings including copper and booster biocides. Unfortunately, the environmental impact of such coatings remains of concern (Bellas 2006; Fernández-Alba et al. 2002) as the decreasing number of European authorized AF biocides testifies (Biocidal Products Regulation, PT 21). Therefore, new biomimetic alternatives have arisen driven by an increased awareness of environmental protection, like the development of fouling release coating technology or the research of natural or bioinspired antifoulants (e.g. (Lejars et al. 2012; Qian et al. 2010).

Particularly, marine natural products have been the subject of considerable bioprospecting studies as they usually have unique chemical structures and a wide range of biological activities (Hu et al. 2015). To date, hundreds of molecules have shown varying degree of activity against a broad range of fouling organisms (Fusetani 2011; Qian et al. 2015). In fact, any natural product capable of inhibiting one or several stages of fouling (e.g. antibacterial, antifungal, antialgal, antilarval) may have a potential as antifoulant. Compounds inhibiting the bacterial adhesion could be viewed as a way to interfere with the first conditioning phase of the biofouling process but also with the subsequent cross-kingdom signaling between biofilms and macrofoulers propagules (Briand 2009; Houdai et al. 2004; Viles et al. 2000; Salta et al. 2013).

In opposition to macroalgae (Pérez et al. 2016) and benthic invertebrates (Fusetani 2004), the AF potential of microalgae has been overlooked. Compared to human and foodborne pathogens, only few microalgal compounds with antibacterial activity against marine fouling bacteria have been characterized to date (Falaise et al. 2016; Mazur-Marzec et al. 2015; Montalvao et al. 2016). While the development of natural product-based paints has been hampered by the difficulty to obtain antifoulants from a sustainable source, microalgae-derived compounds can be obtained via short time large-scale controlled cultures (Qian et al. 2010; Dafforn et al. 2011). This main advantage of microalgae over macroorganisms could often circumvent expensive and challenging laboratory syntheses or the restriction of collection and the inherent difficulty to obtain an adequate supply of invertebrate-sourced molecules (Qian et al. 2010; Pulz and Gross 2004). Such culture-based approach is shared with cultivable marine bacteria that have already been more investigated for AF purpose (Dobretsov et al. 2006).

In addition, photosynthetic microorganisms are represented by a huge diversity of species living in a wide range of ecological habitats (Barra et al. 2014). To survive in such highly diversified and 
competitive environments, tropical microalgae have developed adaptive and defensive strategies. In particular, benthic biofilm-forming microalgae, mainly identified as pennate diatoms (e.g. (Salta et al. 2013), have been reported to produce deterrent chemicals that reduce or prevent biofilm formation (Gademann 2007). A large number of marine microalgae have not been bioprospected yet, especially tropical benthic species, with the exception of species of the genus Lyngbya or Moorea identified as outstanding producers of bioactive metabolites (Taylor et al. 2014). This unexplored chemodiversity from tropical environments constitute a natural heritage that should be preserved and promoted (Hay and Fenical 1996).

Therefore, this study focused on tropical benthic microalgae from the southwest Indian Ocean that may represent an unexplored source of natural and diversified antifoulants. A collection of fifty strains covering six different phyla (Table 1) was screened to study their AF properties. To this end, we used a bioassay targeting the anti-adhesion activity against three marine biofilm-forming bacteria that was designed to discover effective antimicrofouling compounds (Camps et al. 2011; Othmani et al. 2014). Three of the most promising microalgal strains were then selected to test their capacity to inhibit the settlement of barnacle larvae (Othmani et al. 2016b). The toxicity of active fractions was also tested to discuss their potential as sources of environmentally friendly antifoulants. Besides, the chemodiversity of our collection of fifty strains was investigated using metabolomics analyses to explore the differences in metabolic profiles between and within taxa. We expected that this polyphasic approach would allow us to select the most promising strains in order to purify novel ecofriendly antifoulants in further studies.

\section{Materials and methods}

\section{Collection, isolation and cultivation of tropical microalgae}

Fifty strains of tropical benthic microalgae (i.e. including Cyanobacteria), collected from several islands of the southwest Indian Ocean and conserved at the Phytobank collection (Hydrô Reunion, Reunion Island, France) were used in this study. Half of them were isolated directly from environmental biofilm samples (Table 1). They corresponded to 21 strains of Cyanobacteria (i.e. prokaryotes) and 29 strains of microalgae belonging to 5 different phyla [i.e. 19 strains of dinoflagellates (Miozoa), 4 of diatoms (Bacillariophyta), 3 of Cryptophyta, 2 of Rhodophyta and 1 of Haptophyta]. Their isolation and identification were performed as explained in Zea Obando et al. (Zea Obando et al. 2016).

Monospecific non-axenic isolates were grown in batch conditions (from $250 \mathrm{~mL}$ to $5 \mathrm{~L}$ ) in aerated appropriate media at $26^{\circ} \mathrm{C}$ with an irradiance of $20-40 \mu \mathrm{mol} / \mathrm{m}^{2} / \mathrm{s}$ and a $12: 12 \mathrm{~h} \mathrm{light} /$ dark cycle. Media were prepared in filter-sterilized natural seawater and cells were harvested at stationary phase. 
118 Freeze-dried material $(500 \mathrm{mg})$ was extracted sequentially with mixtures of methanol/dichloromethane

$119\left(\mathrm{MeOH} / \mathrm{CH}_{2} \mathrm{Cl}_{2}\right)$ of increasing polarity [1:2, 1:1 and 2:1 (v/v); $\left.3 \times 25 \mathrm{~mL}\right]$. Each macerate was

120 vigorously shaken and then subjected to ultrasounds for $5 \mathrm{~min}\left(20^{\circ} \mathrm{C}\right)$. These macerates were then

121 filtered, pooled and concentrated to dryness under reduced pressure. The resulting crude extract was

122 further fractionated by solid phase extraction (SPE) using dry loading, i.e. dissolution of the extract in

$123 \mathrm{a} \mathrm{MeOH} / \mathrm{CH}_{2} \mathrm{Cl}_{2}(1: 1, \mathrm{v} / \mathrm{v})$ mixture and addition of $1 \mathrm{~g}$ of $\mathrm{C} 18$ bonded-silica (Sepra C18-E, $50 \mu \mathrm{m}$,

124 Phenomenex) before evaporation to complete dryness. SPE cartridges (Strata C18-E, $55 \mu \mathrm{m}, 12 \mathrm{~g}$,

125 Phenomenex) were conditioned with $10 \mathrm{~mL}$ of $\mathrm{MeOH}$ and water, then dried samples were loaded and

126 eluted successively with $10 \mathrm{~mL}$ of water, water/MeOH (1:1, v/v), $\mathrm{MeOH}$ and $\mathrm{CH}_{2} \mathrm{Cl}_{2}$. The four

127 fractions were separately collected, evaporated to dryness and stored at $-20^{\circ} \mathrm{C}$.

\section{Bacterial bioassays}

129 Microalgal fractions giving the best yields were tested for their anti-adhesion property and toxicity

130 against three marine biofilm-forming bacterial strains (i.e. depending on their activity and the amount

131 of extracts available).

132 The three fouling bacterial strains Polaribacter sp. (TC5), Pseudoalteromonas lipolytica (TC8) and

133 Shewanella sp. (TC11) were isolated from the Toulon Bay (Mediterranean Sea, France) between

134 February 2008 and June 2010 (Brian-Jaisson et al. 2014; Camps et al. 2011) and conserved at the

135 Toulon Collection (MAPIEM, Toulon, France). All strains were stored at $-80^{\circ} \mathrm{C}$ in $30 \%$ glycerol

136 medium until use. They were chosen for their different taxonomic, physiological, and biochemical

137 properties (Brian-Jaisson et al. 2014; Camps et al. 2011).

138 For both anti-adhesion and toxicity assays, TC8 was first screened (i.e. lab reference strain) followed

139 by TC11 and TC5.

140 Anti-adhesion assay

141 Anti-adhesion assay was adapted from Camps et al. 2011. The bacterial strains were grown in

142 Väätänen nine salt solution (VNSS) (Holmström et al. 1998) at $20^{\circ} \mathrm{C}$ and $120 \mathrm{rpm}$ and collected at

143 their stationary phase. Growth was monitored by measuring the turbidity $\left(\mathrm{OD}_{600} \mathrm{~nm}\right.$, Genesis 20

144 spectrophotometer, ThermoFischer Scientific). After centrifugation $10 \mathrm{~min}$ at $6000 \mathrm{rpm}$, cell pellet

145 was suspended in sterile artificial seawater (ASW, 36 g/L, Sea Salts, Sigma) and introduced into 96-

146 well black microtiter plates (sterile PS, Nunc, Fisher Scientific). Fractions were tested in triplicates at

$1475-8$ concentrations from 10 to $100 \mu \mathrm{g} / \mathrm{mL}$ concurrently with three controls: (1) non-specific staining

148 control, (2) adhesion control, and (3) solvent control [i.e. ASW/MeOH (95:5, v/v)]. After incubation

149 during an optimized adhesion time (ca. 15h) non-adhered bacteria were eliminated by three successive

150 washes (sterile $\mathrm{NaCl}$ solution, $36 \mathrm{~g} / \mathrm{L}$ ) and adhered cells were quantified using SYTO 61 staining

$151\left(1 \mu \mathrm{M}, \lambda_{\mathrm{exc}}=628 \mathrm{~nm}, \lambda_{\mathrm{em}}=645 \mathrm{~nm}\right.$, ThermoFischer Scientific $)$. Fluorescence measurements for all 
bioassays were made using a TECAN Infinit 200 microplate fluorescence reader and Tecan i-control

1531.10 software.

154 A percent of adhesion was calculated per well, subtracting the value of appropriate non-specific staining control and normalized to the adhesion control. Finally, a sigmoid dose-response curve was obtained by plotting the percentage of adhesion with the log of fraction concentrations. After mean $(n=3)$ and standard deviation (SD) calculation for each concentration, $\mathrm{EC}_{50}$ values (effective concentration for $50 \%$ inhibition of bacterial adhesion) were calculated.

Biological replicates were performed on three independent bacterial cultures when sufficient amount was available and if a bioactivity was first detected (i.e. $\mathrm{EC}_{50}<100 \mu \mathrm{g} / \mathrm{mL}$ ). Only fractions showing $\mathrm{EC}_{50} \leq 60 \mu \mathrm{g} / \mathrm{mL}$ were used to perform the toxicity tests.

\section{Toxicity assays}

163 Bacterial growth inhibition and viability assays were performed based on previous studies of our group (Othmani et al. 2014; Camps et al. 2011). The microtiter plates were filled as for the antiadhesion assay. Briefly, for growth inhibition assay, bacterial growth was monitored in VNSS medium, using the turbidity as a proxy $\left(\mathrm{OD}_{600 \mathrm{~nm}}\right)$, every hour in transparent microtiter plates (sterile PS; Nunc, Fisher Scientific). When reaching the stationary phase, resazurin (50 $\mu \mathrm{M}$, Sigma-Aldrich) was added and fluorescence measured after $2 \mathrm{~h}$ incubation. The growth rate $\mu\left(\mathrm{h}^{-1}\right)$ was calculated during the exponential phase and a percentage of inhibition was deduced. Finally, after mean and SD calculation per triplicate for each concentration, a sigmoid dose-response curve was obtained and $\mathrm{IC}_{50}$ (inhibitory concentration for $50 \%$ of the bacteria) was determined. For viability assay, the same procedure was applied to calculate a $\mathrm{LC}_{50}$ (lethal concentration for $50 \%$ of the bacteria) using resazurin fluorescence.

\section{Barnacle anti-settlement and larval toxicity assays}

Adult and larval barnacle cultures as well as anti-settlement and naupliar toxicity assays were performed with Amphibalanus (= Balanus) amphitrite as explained in Othmani et al. (2016b) and adapted from Rittschof et al. (1992). Solvent controls were 0.1\% MeOH in filtered seawater (FSW, salinity $37 \mathrm{ppm}$ ). Aliquots of the test solutions were pipetted into 24-well polystyrene culture plates (ThermoScientific, France) and air-dried prior addition of $2 \mathrm{~mL}$ of FSW containing 10 organisms. For anti-settlement assays, culture plates containing cyprids were incubated in the dark at $22 \pm 1{ }^{\circ} \mathrm{C}$ for up to 7 days before attached or metamorphosed individuals were counted under a binocular microscope. Toxicity assays were carried out with both nauplii (stage V/VI) and cyprids. After 24 h, larvae were examined for swimming activity or movement under a binocular microscope and categorized as alive, morbid or dead (for calculation of the percentage of mortality, morbid larvae were classified as dead). Only $\mathrm{MeOH}$ fractions of three microalgae were selected for the barnacle bioassays, based on both the antimicrofouling and metabolomics analyses and due to the limitation of extracts. Concentrations 
between 5 and $100-150 \mu \mathrm{g} / \mathrm{mL}$ were tested in triplicate and repeated three times (i.e. twice for P-91) with different nauplii/cyprids batches. Results were expressed as effective concentration inhibiting the settlement of $50 \%$ cyprids $\left(\mathrm{EC}_{50}\right)$ and concentration inducing $50 \%$ morbidity $\left(\mathrm{LC}_{50}\right)$.

\section{Statistical analysis}

Sigmoidal dose-response curves and determination of $\mathrm{EC}_{50}, \mathrm{IC}_{50}$ and $\mathrm{LC}_{50}$ values for each fraction were conducted with GraphPad Prism 5® (GraphPad Software).

\section{Metabolomics analyses}

\section{LC-MS-based metabolomics}

$\mathrm{MeOH}$ eluates from the SPE fractionation of 47 microalgal extracts (i.e. all that remained after bioassays) were used to perform a metabolomics analysis. All samples were standardized at a concentration of $10 \mathrm{mg} / \mathrm{mL}$. Blank samples were $\mathrm{MeOH}$ while quality control samples (QCs) consisted of homogeneous pools of each sample.

LC-MS analyses were conducted on a LaChrom Elite HPLC system (VWR-Hitachi, France) comprising an L-2130 quaternary pump, an L-2200 autosampler and an L-2300 column oven coupled to an ion trap mass spectrometer (Esquire 6000; Bruker Daltonics) fitted with an electrospray ionisation (ESI) interface.

The mass spectrometer parameters were set as follows: dry temperature, $350{ }^{\circ} \mathrm{C}$; capillary voltage, $4000 \mathrm{~V}$; nebulizer, $50 \mathrm{psi}$; dry gas, helium at $12 \mathrm{~L} / \mathrm{min}$. Ion trap full-scan analysis in the positive detection mode was conducted from $\mathrm{m} / \mathrm{z} 50$ to 1200 with an upper fill time of $200 \mathrm{~ms}$. HPLC separation was achieved on an analytical reversed-phase column (Gemini C6-phenyl, $5 \mu \mathrm{m}$, $250 \times 3 \mathrm{~mm}$; Phenomenex) using a 65 min linear gradient elution of $\mathrm{H}_{2} \mathrm{O} / \mathrm{ACN} /$ formic acid. The gradient started from 90:10:0.1 (v/v/v, isocratic from 0 to $5 \mathrm{~min})$ to 0:100:0.1 (v/v/v) in $35 \mathrm{~min}$, held for $20 \mathrm{~min}$ before re-equilibration of the system for $10 \mathrm{~min}$ with the initial conditions. The flow rate was $0.5 \mathrm{~mL} / \mathrm{min}$, the column temperature $30{ }^{\circ} \mathrm{C}$ and the injection volume was $10 \mu \mathrm{L}$. All solvents were of LC-MS-grade. Ultrapure water was prepared using a Milli-Q water system (Millipore). QCs were injected at both the beginning and the end and every 5 samples of the sequence injection to ensure analytical repeatability. To limit time-dependent changes in LC-MS chromatographic analyses, microalgal extracts and blank samples were randomly injected.

\section{Data preprocessing and filtering}

Data Analysis 4.3 software (Bruker Daltonics) was used to convert chromatograms to netCDF files as line spectra. Data preprocessing was then performed with the XCMS software (Smith et al. 2006) under the R 3.1.0 environment. Peak picking was performed with the "matchedFilter" method ("snthresh" =5), retention time correction with the "obiwarp" method ("profstep" =0.1), peak 
grouping with " $b w "=30$ and "mzwidth" $=0.25$ and gap filling with the "FillPeaks" method (using default parameters).

The matrix containing the list of 797 features with their retention time, $\mathrm{m} / \mathrm{z}$ value and intensity was exported to SIMCA-P 13.0.3 software (Umetrics, Sweden). Data were log10-transformed and Paretoscaled. Principal component analysis (PCA) was used to explore the chemical diversity across the studied tropical microalgae.

\section{NMR-based metabolomics}

Sample preparation

Extraction of microalgae for NMR-based metabolomics was different. Freeze-dried material $(50 \mathrm{mg})$ of the 47 strains was extracted with $1.5 \mathrm{~mL}$ of deuterated chloroform $\left(\mathrm{CDCl}_{3}\right)$ containing $0.03 \%$ tetramethylsilane (TMS) by vortexing $5 \mathrm{~min}$ at $25^{\circ} \mathrm{C}$ and $1700 \mathrm{rpm}$. Samples were ultrasonicated for $15 \min \left(45 \mathrm{kHz}, 35^{\circ} \mathrm{C}\right)$ and centrifuged at $13000 \mathrm{rpm}$ for $20 \mathrm{~min}$. Aliquots of $0.7 \mathrm{~mL}$ were used for NMR analysis.

\section{NMR measurements}

234 The ${ }^{1} \mathrm{H}-\mathrm{NMR}$ experiments were performed at $25^{\circ} \mathrm{C}$ on an Avance II 600 NMR spectrometer (Bruker, 235 Rheinstetten, Germany) equipped with a cryoprobe operating at a proton NMR frequency of $236 \quad 600.18 \mathrm{MHz}$. $\mathrm{CDCl}_{3}$ was used for internal lock. A total of 128 scans spectra with a spectral width of $16,019 \mathrm{~Hz}$ were recorded with pulse width $=30^{\circ}$ and relaxation delay $=1 \mathrm{~s}$.

\section{Data and statistical analyses}

239 Prior to Fourier transformation, the free induction decays (FIDs) were zero-filled to 65536 points and an exponential window function with a line broadening of $0.3 \mathrm{~Hz}$ was applied. The resulting spectra were manually phased, baseline corrected and referenced to internal TMS at $0.00 \mathrm{ppm}$ using MestReNova 10.0 software (Mestrelab Research S.L., Spain). The ${ }^{1}$ H-NMR spectra were then automatically binned. Spectral intensities were normalized to total intensity and reduced to integrated regions of equal width $(0.04 \mathrm{ppm})$ corresponding to the region of $\delta 0.58-10.02 \mathrm{ppm}$. The region $\delta 7.06-7.42 \mathrm{ppm}$ was removed because of the residual solvent signal. PCA was performed on the Pareto-scaled dataset using SIMCA 13.0.

\section{Results}

\section{Anti-adhesion activity against bacteria}

Crude extracts of the 50 microalgal strains were further fractionated by SPE, leading to 200

250 fractions. In total, 84 fractions [i.e. 35 aqueous, $19 \mathrm{MeOH} / \mathrm{H}_{2} \mathrm{O}(1: 1, \mathrm{v} / \mathrm{v})$, and $30 \mathrm{MeOH}$ eluates] were assessed for their anti-adhesion activity against one, two or the three pioneer biofilm-forming marine bacteria. The choice for the fractions to be tested was guided by their amount (i.e. the mass obtained 
after SPE; aqueous fractions being the most concentrated) and their solubility in seawater (which excluded the $\mathrm{CH}_{2} \mathrm{Cl}_{2}$ fractions). No aqueous fractions were active while only two of the $\mathrm{MeOH} 50 \%$ fractions were weakly or moderately active on Polaribacter sp. TC5 with $\mathrm{EC}_{50}$ values of 83 and $47 \mu \mathrm{g} / \mathrm{mL}$ for the unidentified Cyanobacteria C-09 and the dinoflagellate Symbiodinium sp. P-73, respectively (data not shown). The anti-adhesion activity was concentrated in $\mathrm{MeOH}$ fractions as they represented 28 out of the 30 active fractions while only two $\mathrm{MeOH}$ fractions were not active.

Depending on both the microalgae and the targeted bacterium, different degrees of activity were observed, spanning from very highly $\left(\mathrm{EC}_{50}=1-10 \mu \mathrm{g} / \mathrm{mL}\right)$, highly $\left(\mathrm{EC}_{50}=11-30 \mu \mathrm{g} / \mathrm{mL}\right)$, moderately $\left(\mathrm{EC}_{50}=31-50 \mu \mathrm{g} / \mathrm{mL}\right)$ and weakly active $\left(\mathrm{EC}_{50}=50-100 \mu \mathrm{g} / \mathrm{mL}\right)$ to not active $\left(\mathrm{EC}_{50}>100 \mu \mathrm{g} / \mathrm{mL}\right)$ (Fig. 1). The activity of the tributyltin oxide (TBTO) was mentioned as a reference for our bioassay and $\mathrm{EC}_{50}$ values were between 1.2 and $14 \times 10^{-3} \mu \mathrm{g} / \mathrm{mL}$, ca. 1000 times lower than the most active microalgal fraction. Interestingly, anti-adhesion activity was detected among all phyla. Indeed, 8/21 Cyanobacteria, 14/19 dinoflagellates, the four diatoms, 2/3 Cryptophyta, 1/2 Rhodophyta and the only Haptophyta showed some antimicrofouling potential. Nevertheless, most highly active fractions were obtained from dinoflagellates, especially from species of the genus Amphidinium. Notably, two strains (i.e. Amphidinium gibbosum P-43 and Symbiodinium sp. P-78) were very highly active against the three bacteria while only two non-dinoflagellate fractions (i.e. one of the cryptophyte P-68 and one of the Cyanobacteria C-59) showed very high activities but only against one of the bacteria. Noteworthy, the fractions derived from microalgae isolated from biofilms also had high activities, particularly two out of the four diatoms and some Cyanobacteria (e.g. C-59 and C-61).

\section{Toxicity against bacteria}

We evaluated the impact of the $\mathrm{MeOH}$ microalgal fractions on both the growth and the viability of the three biofilm-forming marine bacteria. Bioassays were performed if an $\mathrm{EC}_{50}$ value $\leq 60 \mu \mathrm{g} / \mathrm{mL}$ was obtained for at least one bacterium and when sufficient material was still available (Fig. 2).

$\mathrm{MeOH}$ fractions with promising anti-adhesion activities also exhibited important growth inhibition as 42, 71 and $100 \%$ of the tested fractions were active on TC11, TC8 and TC5, respectively. Even though TC5 seemed more sensitive than the two other strains, the comparison of bacterial strains sensitivity is hampered by the fact that the number of tested fractions differed between the three strains (17/18 for TC8, 12/18 for TC11 and 9/18 for TC5, i.e. due to the lack of material). Strains of the genus Amphidinium gave the most active fractions with $\mathrm{IC}_{50}$ values $\leq 50 \mu \mathrm{g} / \mathrm{mL}$ for all but two bacterial fractions (i.e. P-44 and P-63 on TC11), followed by Pavlova sp. P-69 and the cryptophyte P-68. However, few fractions were lethal to the bacteria. Again, Polaribacter sp. TC5 appeared more sensitive than the other two strains, with $\mathrm{LC}_{50}$ values $\leq 50 \mu \mathrm{g} / \mathrm{mL}$ for the six out of the nine active fractions. Only two fractions were weakly toxic to Shewanella sp. TC11. P. lipolytica TC8 had an intermediate sensitivity as $41 \%$ of the tested fractions were active, including two that were highly toxic with $\mathrm{LC}_{50}$ values $\leq 30 \mu \mathrm{g} / \mathrm{mL}$ (i.e. Pavlova sp. P-69 and Symbiodinium sp. P-78). 
While almost all toxic microalgae also had some growth inhibition activity, four strains were only toxic to the bacteria (i.e. the diatoms Nitzschia sp. P-89 and Psammodictyon sp. aff. constrictum P-90 and the Cyanobacteria Pseudanabaena sp. C-30 and Synechococcus elongatus C-60), suggesting a specific mode of action. The opposite trend was observed for the unidentified cryptophyte P-68 which was non-toxic but inhibited the growth of the three bacteria. The underpinning mechanisms of both growth inhibition and toxicity were beyond the scope of this study.

Finally, the selectivity index (SI) also called therapeutic ratio (Rittschof et al. 1992) and defined as the ratio of $\mathrm{LC}_{50}$ and $\mathrm{EC}_{50}$, was calculated. Eight out of the nine dinoflagellate-derived fractions and only one non-dinoflagellate fraction (i.e. for the cryptophyte P-68) had a SI $\geq 10$ for at least one of the bacteria. Concerning the other phyla, SI were always $\leq 4$, independently of the bacterial strains. SI values were strain-dependent but highest for TC11 as this strain was more resistant. Values for TBTO ( $\mathrm{IC}_{50}, \mathrm{LC}_{50}$ and $\left.\mathrm{SI}\right)$ were added as references. While being less active in the antiadhesion bioassay, $\mathrm{MeOH}$ fractions of microalgae were about 3500-30 000 times less acutely toxic than TBTO and thus had generally better SI.

\section{Anti-settlement activity and toxicity against barnacle larvae}

Two dinoflagellates of the genus Amphidinium (P-43 and P-60) and the diatom Navicula mollis P91 were selected to perform barnacle bioassays (Table 2). These strains were chosen based on the availability of the remaining extracts and both their antimicrofouling potential and chemodiversity (Fig. 3, Appendices A and B). The three $\mathrm{MeOH}$ fractions showed a significant anti-settlement activity with $\mathrm{EC}_{50}$ values $\leq 45 \mu \mathrm{g} / \mathrm{mL}$. Navicula mollis P-91 fraction was ca. 5 times more active than those of the dinoflagellates P-43 and P-60. Cytotoxicity towards A. amphitrite stage V/VI nauplii and cyprids was strain-dependent. Interestingly, no acute toxicity for both nauplii and cyprids was observed for P91 , even at the highest concentrations $\left(24 \mathrm{~h}-\mathrm{LC}_{50}>100 \mu \mathrm{g} / \mathrm{mL}\right.$ ) while dinoflagellates showed some toxicity on cyprids.

\section{Metabolomics analyses}

Metabolomics analyses were performed to evaluate the chemodiversity of the tropical microalgae.

315 Only chromatographic profiles obtained with $\mathrm{MeOH}$ fractions were considered for LC-MS-based

316 metabolomics as anti-adhesion activity was predominantly detected in these fractions.

317 The PCA score plot of 46 out of the 50 strains initially studied was represented on Fig. 1. The four 318 missing fractions corresponded to three fractions that were no longer available (i.e. cyanobacterial strains C-30, C-33 and C-58) and the exclusion of C-64 (Porphyridium sp.) as it clustered with the blanks. The total variance due to the two main axis accounted for $45 \%$ on the PCA score plots. The distinction between prokaryotes (i.e. Cyanobacteria) and eukaryotes is clearly visible on the first component (27\%), with few exceptions (i.e. the eukaryotes C-03, P-04, P-67 and P-92 clustered with 
Cyanobacteria) while the second component (17\%) allowed the distinction between diatoms and Cryptophyta.

Although the sizing of symbols by bioactivity confirmed the better anti-adhesion activity of dinoflagellates, other strains (e.g. the Cyanobacteria C-59 or the diatoms P-90 and P-91) had interesting activities while being in separate clusters, thus displaying different chemical profiles. To verify that the clustering obtained with LC-MS-based metabolomics was not biased by the specific sample preparation, we also performed an NMR-based metabolomics analysis using organic crude extracts (Supp Figure 1). The two main axes accounted for a better total variance of $71.3 \%$. In these conditions, C-64 was not an outlier and a few exceptions with the taxa-based clustering were also noted. The presence of the C-03 and P-67 strains in the Cyanobacteria group was in agreement with the LC-MS-based metabolomics. However, considering diatoms, P-89 was clearly in the dinoflagellates group considering NMR profiles, whereas P-92 did not cluster with the three other diatom strains considering LC-MS profiles. Both metabolomics approaches revealed that Cyanobacteria and dinoflagellates were scattered groups, indicating metabolic specificity thus chemodiversity within these two phyla. A more specific analysis of the metabolomics dataset of these two phyla allowed, through the building of OPLS-DA models, to highlight some putative biomarkers. A focus was made on the most discriminating $\mathrm{m} / \mathrm{z}$ variables and NMR chemical shifts (Supp Figures 2 and 3). More precisely, variables with $\mathrm{m} / z 587.5$ and $\mathrm{m} / \mathrm{z} 589.5$ were specifically produced in cyanobacterial samples and could be related to the occurrence of phycobilins in such extracts (Fu et al. 1979; Singh and Verma 2012). In the case of NMR data, several of the ${ }^{1} \mathrm{H}$ NMR bins overexpressed in dinoflagellates ranged between 4.00 and $3.50 \mathrm{ppm}$ and between 5.00 and $5.50 \mathrm{ppm}$ and thus could be attributed to acylglycerols with polyunsaturated fatty acids (Nieva-Echevarría et al. 2014).

\section{Discussion}

The discovery of environmentally friendly molecules that effectively prevent biofouling remains a challenge in the marine antifoulant research field (Dafforn et al. 2011; Qian et al. 2015). New biomimetic solutions could be developed when considering the natural mechanisms implemented by marine organisms to protect themselves (e.g. against epibiosis) (Aguila-Ramirez et al. 2014; Scardino and de Nys 2011). A key point could be that a single molecule would never have a chance to inhibit the huge diversity of biofoulers colonizing surfaces in the marine environment. For this reason, this work aimed to study extracts/fractions and not pure compounds which required time-consuming and costly purification and characterization steps while not necessarily being ecologically relevant. In addition to the possibility to inhibit the adhesion of several organisms, considering extracts/fractions allowed to benefit from likely synergism between compounds.

This study focused on benthic microalgae that were collected from different islands of the southwest Indian Ocean (i.e. 23 from Reunion Island, 14 from the Scattered Islands, 7 from Mayotte, 5 
from Madagascar and 1 from Mauritius) between 1992 and 2013. Hitherto, studies about microalgae from this were mainly restricted to toxic dinoflagellates (e.g. Ostreopsis spp. which produce one of the most potent non-protein toxin (Lenoir et al. 2004)). Thus, the biotechnological potential of such organisms in the field of AF was unknown. Our collection was very diverse, although dominated by two out of the six phyla (dinoflagellates and Cyanobacteria represented $38 \%$ and $42 \%$ of the 50 strains, respectively). The four diatoms and almost all Cyanobacteria (i.e. 19/21 strains) were isolated directly from marine biofilms (Landoulsi et al. 2011; Salta et al. 2013). These autotrophs, especially Cyanobacteria, are major components of tropical biofilms (Viles et al. 2000; Paul et al. 2005). It has also been suggested that these biofilm-forming microalgae can produce a variety of chemical deterrents for defense purposes. Hence, they may show some AF properties (Dobretsov et al. 2006; Leao et al. 2012).

\section{Anti-adhesion activity}

When searching for AF compounds intended to protect man-made devices, bacteria adhering on artificial substrata should be tested (Briand 2009; Camps et al. 2011). The three bacterial strains used here (TC5, TC8 and TC11) were isolated from marine biofilms formed after a few hours on immersed artificial substrata in a temperate area (Brian-Jaisson et al. 2014). We have also isolated a set of bacterial strains from artificial surfaces immersed at the Reunion Island (i.e. tropical area), which showed a similar sensitivity against AF biocides compared to the three temperate ones (data not shown). Therefore, we considered that TC5, TC8 and TC11 temperate strains, for which previous data were available (e.g. Brian-Jaisson et al. 2014; Camps et al. 2011; Othmani et al. 2014; Othmani et al. 2016a; Othmani et al. 2016b; Favre et al. 2017), were suitable targets to assess AF potential of tropical microalgae. Interestingly, targeting the inhibition of fouling bacteria adhesion may further prevent or reduce both the micro- and macrofouling of submerged structures. Indeed, some microfoulers (e.g. bacteria, especially of the genus Pseudoalteromonas and diatoms) have been reported to regulate the settlement of macrofoulers via chemical cues (Hadfield 2011; Qian et al. 2007).

The screening of anti-adhesion activity among the 50 microalgal strains revealed that the $\mathrm{AF}$ potential varied widely depending on the polarity of the crude extract, the species and, to a lesser extent, the fouling bacteria tested. The higher sensitivity of TC5 in all bioassays was already reported $[22,24,68]$ and may be related to its lower ability to form substantial biofilms in vitro (Brian-Jaisson et al. 2014). Bioactivity was considered fraction-specific as $93 \%$ of the 30 active samples were methanolic fractions and none of the 35 aqueous fractions inhibited the adhesion of bacteria. In agreement with our results, Falaise et al. reviewed that antimicrobial activity of microalgae was generally found in methanolic and other organic extracts (Falaise et al. 2016).

It is interesting to note that microalgae from all taxa, independently of their origin, showed some activity. Mudimu and collaborators hypothesized that the capacity to produce antibacterial and antifungal compounds has evolved independently of phylogenetic relationship in both microalgae and 
Cyanobacteria (Mudimu et al. 2014). However, dinoflagellate species assayed here, especially Amphidinium and Symbiodinium strains, were the most active. While marine dinoflagellates have proved to be an important source of bioactive natural products (e.g. Van Wagoner et al. 2014), antimicrobial activity derived from dinoflagellate extracts or compounds has rarely been reported so far. Only a few studies observed antimicrobial properties for compounds isolated from Amphidinium spp., e.g. amphidinins C-F and luteophanol A (Doi et al. 1997; Kubota et al. 2014). Most of the dinoflagellates screened in this study are sand-dweller or benthic species with predominantly motile cells. From an ecological point of view, their capacity to inhibit the growth of bacterial competitors could be less critical than for sessile benthic taxa which settle on surfaces in more diversified microbial communities.

Concerning the microalgae isolated directly from biofilms, Cyanobacteria had surprisingly a general moderate activity while diatoms, and in particular Navicula mollis P-91, were highly active. Cyanobacteria are a very prolific source of bioactive metabolites (Leao et al. 2012) and they are known to display a rich chemodiversity (Burja et al. 2001). Even if some reports seemed to prone their potential application as antimicrofoulants (e.g. Bhadury and Wright 2004; Gademann 2007), others reached similar conclusions to our own. For example, during a bioprospecting of Cyanobacteria from the Baltic Sea, only three out of 27 strains were reported to weakly inhibit the growth of fouling $\gamma$ Proteobacteria (Mazur-Marzec et al. 2015). However, it should be noted that only nine of the Cyanobacterial strains gave sufficient material to perform bioassays in our study. Thus, the antimicrofouling potential of the twelve other strains cannot be ruled out.

Diatoms may hide a potential for AF compound production according to Dobretsov et al. (2006). In previous studies, extracts from Attheya longicornis (Ingebrigtsen et al. 2016), Amphiprora paludosa (Sanchez-Saavedra et al. 2010), Nitzschia communis and Amphora cf. capitellata (Montalvao et al. 2016), and polyunsaturated fatty acids (e.g. hexadecatetraenoic, eicosapentaenoic and hexadecatrienoic acids) from Chaetoceros muelleri (Falaise et al. 2016), Navicula delognei (Findlay and Patil 1984) and Phaeodactylum tricornutum (Desbois et al. 2008; Desbois et al. 2009) have shown interesting antibacterial activities. Moreover, blue pigments from Haslea ostrearia and $H$. karadagensis were found to be active against three marine fungi implicated in biofouling (Gastineau et al. 2012a, b).

Among strains belonging to the three other taxa, moderate anti-adhesion activity was detected for the rhodophyte C-64 Porphyridium sp. whereas the haptophyte Pavlova sp. P-69 was highly active against the three bacteria. The two strains of Cryptophyta (P-68 and P-70) showed in-between activities. To date, some Porphyridium spp. have shown antibacterial activities, e.g. organic extracts of P. purpureum, P. aerugineum or $P$. cruentum (Falaise et al. 2016; Sanchez-Saavedra et al. 2010; Guedes et al. 2011) while phycobiliproteins of $P$. aerugineum and $P$. cruentum were both antibacterial and antifungal (Najdenski et al. 2013). AF potential of haptophytes is poorly documented and only two antibacterial chlorophyll a degradation products from Isochrysis galbana have been reported 
(Falaise et al. 2016). Finally, we could not find any report of bioactivity concerning Cryptophyta. However, one of our unidentified strains (P-68) showed significant anti-adhesion activity against the three bacteria tested that may involve some growth inhibition mechanism considering toxicity results.

It is well recognized that AF activity should include the capacity to disturb the adhesion of a wide range of foulers. Among them, barnacle represents a key species, especially because of its wide distribution and, as encrusting taxa, the huge damage associated with its settlement (Aldred and Clare 2008). Thus, the potential to prevent adhesion of the barnacle model A. amphitrite was also assessed with three microalgal fractions selected for their interesting antibacterial adhesion activity. The two dinoflagellate (i.e. from Amphidinium gibbosum P-43 and A. carterae P-60) showed moderate activity while the diatom Navicula mollis P-91 exhibited a remarkable ability to inhibit the adhesion of $A$. amphitrite. This is the first time to our knowledge that a benthic diatom isolate coming from a marine biofilm was shown to be potentially involved in the prevention of invertebrate adhesion.

It is of great interest for our screening to identify natural extracts inhibiting several target species. Some other interesting activities from microalgae have been reported against biofouling, in addition to antibacterial compounds. For example, antifungal or algicidal molecules have been purified from Amphidinium species (Houdai et al. 2004; Washida et al. 2006; Kong et al. 2016). Similar activities have also been observed in Cyanobacteria and Rhodophyta (Najdenski et al. 2013; Berry et al. 2008). Besides, Almeida et al. noted that aqueous extracts of Synechocystis strains isolated from Atlantic coasts showed interesting molluscicidal activities (Almeida et al. 2015). That result should also be considered regarding the interactions between biofilms and invertebrate larval recruitment. If the bacterial role has already been investigated as previously mentioned (Hadfield 2011; Qian et al. 2007; Salta et al. 2013), the role of major autotrophs in biofilms, i.e. the diatoms, in the control of larval recruitment has been overlooked.

\section{Toxicity of the tropical microalgae}

Inhibition of bacterial adhesion (i.e. biofilm formation) or cyprid settlement may result either from specific inhibition of the adhesion process itself or as a consequence of toxicity. In order to discuss the actual potential of tropical microalgae as sources of environmentally friendly antifoulants, we studied the toxicity of active fractions on the three fouling bacteria and on two stages of barnacle life cycle. Generally, when SI, i.e. the ratio of bioactivity and toxicity, is higher than 10 to 15 (Rittschof et al. 1992; Qian et al. 2010), extracts or compounds are assumed to be non-toxic. strains had selective indexes lower than four. These lower SI reflected more the less potent antiadhesion activity of non-dinoflagellate microalgae rather than their toxicity, except for the haptophyte Pavlova sp. P-69 which was highly toxic against TC8 and TC5.

Therefore, considering only SI, almost all dinoflagellate strains studied here may be sources of 
activity on the three marine bacteria, in contrast to diatoms and Cyanobacteria. Moreover, many toxic compounds have been isolated from dinoflagellates of the genus Amphidinium, Symbiodinium and Prorocentrum (Kobayashi and Kubota 2007; Gordon and Leggat 2010; Ten-Hage et al. 2002; Neves et al. 2017) that might explain their relative higher toxicity in this study, including on barnacles. Indeed, the anti-settlement activity of dinoflagellate fractions appeared to be associated with toxic compounds. Thus, resulting therapeutic ratio (i.e. $>10$ for P-91 and $<3$ for P43 and P-60) suggested that anti-settlement activity of Navicula mollis P-91 was likely due to molecules that may specifically hinder adhesion mechanisms of barnacle, in opposition to intrinsic toxicity of Amphidinium P-43 and P-60 fractions. Noteworthy, toxicity of the two dinoflagellates was noted only for cyprid larvae (i.e. the stage at which barnacle larva are able to attach to surfaces).

Despite their weak bacterial growth inhibition described here, toxicity of Cyanobacteria and diatoms has also been reported against several types of organisms. For examples, extracts of Synechocystis and Leptolyngbya spp. were found to induce acute toxicity to Artemia salina nauplii, to sea urchin larvae while they completely inhibited the embryogenesis of the Mediterranean mussel (Martins et al. 2007; Lopes et al. 2010). Concerning diatoms, even though none of the Navicula and Nitzschia strains screened by Wichard et al. produced oxylipins (Wichard et al. 2005), many diatoms can produce these very reactive aldehydes that were highly cytotoxic to six different phyla including copepods, oysters and sea urchins (Adolph et al. 2004). Fortunately, the active diatom strains tested in this work showed no toxicity towards bacteria and barnacle larvae but ecotoxicological tests should be performed on a wider diversity of marine organisms, as well as screening for domoic acid production. Indeed, this neurotoxin responsible for Amnesic Shellfish Poisoning (ASP) in humans and accumulating in organisms of higher trophic levels (Saeed et al. 2017), has recently been discovered in Nitzschia bizertensis sp. (Smida et al. 2014) and Nitzschia navis-varingica (Suriyanti and Usup 2015). Toxicity information should be considered before the selection of tropical microalgae for future possible costly works (e.g. cultivation at large scale, purification and assessment of in situ activity of AF compounds).

\section{Chemodiversity of tropical microalgae}

Metabolomics is the global measurement of metabolites in biological systems that reflect the phenotype. It is ultimately the result of underlying genomic, transcriptomic, and proteomic networks (Fiehn 2002). Combining PCA with analytical tools such as liquid chromatography tandem mass spectrometry is an attractive method to provide a visual representation of differences between LC-MS profiles (Hou et al. 2012; Othmani et al. 2016a; Favre et al. 2017). Indeed, microalgae producing similar metabolites would group together and vice versa. Considering our sample preparation procedure (i.e. fractionation of $\mathrm{MeOH} / \mathrm{CH}_{2} \mathrm{Cl}_{2}$ crude extracts into four fractions of decreasing polarity for bioassay purpose), the clustering observed on the PCA score plots was very interesting. Indeed, the groups observed were confirmed by a NMR-based metabolomics approach with the whole organic 
extracts and corresponded to the four main taxa (i.e. Cyanobacteria, dinoflagellates, diatoms and Cryptophyta while Rhodophyta and Haptophyta cannot be considered as only one strain was available for both phyla). These results suggested that both methods were valuable to evaluate the chemodiversity of tropical microalgae.

Previously, the clear separation between our Cyanobacteria and dinoflagellate strains had already been reported using in vivo ${ }^{1} \mathrm{H}$ HR-MAS NMR spectroscopy (Zea Obando et al. 2016). However, we unexpectedly observed the presence of four eukaryotic strains in the Cyanobacteria cluster with LCMS-based metabolomics; some (e.g. the rhodophyte C-03) were confirmed by the NMR-based approach. It may result from the presence of common compounds like phycobiliproteins, or, more probably, from the degradation of these fractions. The biodiversity of microalgae was thus reflected by both the inter- and intraspecific metabolic profiles which is interesting for a bioprospecting purpose. Using metabolomics, even with low resolution mass spectrometry on fractionated extracts, we were able to highlight the chemodiversity of tropical microalgae without identifying the composition of each extract or having the precise identification of all strains. Indeed, the heatmap of metabolites showed only partial overlap between selected strains (Supp Figure 4). As evidenced by Hou et al. (2012) and supported by this preliminary study, the LC/MS-PCA combination should be useful for the selection of strains displaying maximal chemical diversity for the discovery of novel antifoulants.

\section{Selection of the most promising tropical microalgae}

Based on all our results, i.e. anti-adhesion activity, toxicity and chemodiversity, up to five strains could be selected for in-deep study of their AF potential, namely the unidentified cryptophyte P-68, the Cyanobacteria Gloeocapsopsis sp. C-61, the dinoflagellates Amphidinium gibbosum P-43 and A. carterae P-60 and finally the diatom Navicula mollis P-91.

Benthic marine microalgae have been neglected for bioprospecting purpose, possibly due to culture issues (Barra et al. 2014). However, the fifty strains studied here were successfully cultivated in up to 5 L flasks. Besides, A. carterae has shown a good potential regarding culture scale-up (FuentesGrünewald et al. 2016) as well as Cyanobacteria like Spirulina (Xu et al. 2009) or benthic diatoms (Raniello et al. 2007). Further studies on the purification and identification of active compounds from the selected strains will be conducted to characterize natural eco-friendly antifoulants. So far, antimicrobial compounds isolated from microalgae were mainly fatty acid-related compounds or, to a lesser extent, pigments (Falaise et al. 2016). Other chemical families structures, e.g. lactones are promising like for honaucins isolated from the marine Cyanobacteria Leptolyngbya crossbyana (Choi et al. 2012) which inhibited quorum sensing, a form of cell-cell communication essential in microbial surface colonization (Dang and Lovell 2016).

Another advantage of microalgae is that culture conditions can be manipulated and optimized to the overexpression or accumulation of metabolites of interest, which is known as metabolic induction concept (Abida et al. 2013). The production of bioactive compounds by microalgae varies according to 
growth conditions, availability and concentration of nutrients in the culture medium, light intensity, temperature and/or pH (Noaman et al. 2004; Ingebrigtsen et al. 2016; Bagwell et al. 2016; Volk and Furkert 2006). Thus, the AF potential of tropical microalgae could be further increased after the optimization of culture conditions for the production of AF agents.

Biofouling is a very complex process that cannot be fully replicated by laboratory single-species bioassays. Hence confirmation of the anti-adhesion activity of selected tropical microalgae would be required using at least mixed-species biofilms in vitro or by field studies (Burgess et al. 2003; Briand 2009; Lee et al. 2014). Specifically, the methanolic fractions of Amphidinium P-43 and P-60 strains and Navicula mollis P-91 have shown interesting antimicro- and antimacrofouling properties thus they should be incorporated in several type of coatings for in situ tests.

\section{Conclusion}

In this study, we presented the results of the large-scale screening of the AF properties of fifty tropical microalgae including Cyanobacteria. The metabolomics analyses revealed the untapped chemodiversity of our collection of tropical strains. Methanolic fractions from strains of all six phyla inhibited to some extent the adhesion of the three fouling bacteria tested. Dinoflagellates were highly active but also the more toxic. One diatom strain especially exhibited a promising potential for the inhibition of the adhesion of both biofilm bacteria and barnacle larvae. Together, these results allowed us to select five strains with very promising potential as sources of environmentally friendly antifoulants. However, in addition to the complete chemical characterization of the active extracts, further field studies with microalgae extract-based coatings are required to better characterize the actual AF potential of these tropical microalgae.

\section{Acknowledgements}

This study was funded by the French National Research Agency (project BioPainTrop, ANR-12CDII-0008). The authors would particularly like to thank Dr. Nicolas Chomérat (Ifremer, France), Maurice Loir and Dr. Mitsunori Iwataki (University of Tokyo, Japan), for their help in Amphidinium, Prorocentrum and Navicula species identification. They also would like to thank Qiong-Yao Xue, Emmanuelle Espuche and Lucie Bruno for technical assistance (extraction of microalgae and some bioassays).

\section{References}

Abarzua S, Jakubowski S (1995) Biotechnological investigation for the prevention of biofouling. 1. Biological and biochemical principles for the prevention of biofouling. Mar Ecol Prog Ser 123 (1-3):301-312. doi:http://dx.doi.org/10.3354/meps123301 
Abida H, Ruchaud S, Rios L, Humeau A, Probert I, De Vargas C, Bach S, Bowler C (2013) Bioprospecting marine plankton. Marine Drugs 11 (11):4594-4611. doi:10.3390/md11114594 Adolph S, Bach S, Blondel M, Cueff A, Moreau M, Pohnert G, Poulet SA, Wichard T, Zuccaro A (2004) Cytotoxicity of diatom-derived oxylipins in organisms belonging to different phyla. Journal of Experimental Biology 207 (17):2935-2946. doi:http://dx.doi.org/10.1242/jeb.01105 Aguila-Ramirez RN, Hernandez-Guerrero CJ, Gonzalez-Acosta B, Id-Daoud G, Hewitt S, Pope J, Hellio C (2014) Antifouling activity of symbiotic bacteria from sponge Aplysina gerardogreeni. International Biodeterioration \& Biodegradation 90:64-70. doi:http://dx.doi.org/10.1016/j.ibiod.2014.02.003

Aldred N, Clare AS (2008) The adhesive strategies of cyprids and development of barnacle-resistant marine coatings. Biofouling 24 (5):351-363. doi:10.1080/08927010802256117

Almeida JR, Freitas M, Cruz S, Leao PN, Vasconcelos V, Cunha I (2015) Acetylcholinesterase in biofouling species: Characterization and mode of action of cyanobacteria-derived antifouling agents. Toxins 7 (8):2739-2756. doi:http://dx.doi.org/10.3390/toxins7082739

Bagwell CE, Abernathy A, Barnwell R, Milliken CE, Noble PA, Dale T, Beauchesne KR, Moeller PDR (2016) Discovery of bioactive metabolites in biofuel microalgae that offer protection against predatory bacteria. Frontiers in Microbiology 7. doi:http://dx.doi.org/10.3389/fmicb.2016.00516

Barra L, Chandrasekaran R, Corato F, Brunet C (2014) The challenge of ecophysiological biodiversity for biotechnological applications of marine microalgae. Marine Drugs 12 (3):1641-1675. doi:http://dx.doi.org/10.3390/md12031641

Bellas J (2006) Comparative toxicity of alternative antifouling biocides on embryos and larvae of marine invertebrates. Sci Total Environ 367 (2):573-585. doi:http://dx.doi.org/10.1016/j.scitotenv.2006.01.028

Berry JP, Gantar M, Perez MH, Berry G, Noriega FG (2008) Cyanobacterial toxins as allelochemicals with potential applications as algaecides, herbicides and insecticides. Marine Drugs 6 (2):117146. doi:http://dx.doi.org/10.3390/md20080007

Bhadury P, Wright PC (2004) Exploitation of marine algae: Biogenic compounds for potential antifouling applications. Planta 219 (4):561-578. doi:http://dx.doi.org/10.1007/s00425-004$1307-5$

Brian-Jaisson F, Ortalo-Magne A, Guentas-Dombrowsky L, Armougom F, Blache Y, Molmeret M (2014) Identification of bacterial strains isolated from the Mediterranean Sea exhibiting different abilities of biofilm formation. Microb Ecol 68 (1):94-110. doi:http://dx.doi.org/10.1007/s00248-013-0342-9

Briand JF (2009) Marine antifouling laboratory bioassays: an overview of their diversity. Biofouling $25(4): 297-311$ 
Burgess JG, Boyd KG, Armstrong E, Jiang Z, Yan L, Berggren M, May U, Pisacane T, Granmo A, Adams DR (2003) The development of a marine natural product-based antifouling paint. Biofouling 19 (sup1):197-205. doi:http://dx.doi.org/10.1080/0892701031000061778

Burja AM, Banaigs B, Abou-Mansour E, Burgess JG, Wright PC (2001) Marine cyanobacteria - a prolific source of natural products. Tetrahedron 57 (46):9347-9377. doi:http://dx.doi.org/10.1016/s0040-4020(01)00931-0

Camps M, Briand JF, Guentas-Dombrowsky L, Culioli G, Bazire A, Blache Y (2011) Antifouling activity of commercial biocides vs. natural and natural-derived products assessed by marine bacteria adhesion bioassay. Mar Pollut Bull 62 (5):1032-1040. doi:http://dx.doi.org/10.1016/j.marpolbul.2011.02.031

Choi H, Mascuch Samantha J, Villa Francisco A, Byrum T, Teasdale Margaret E, Smith Jennifer E, Preskitt Linda B, Rowley David C, Gerwick L, Gerwick William H (2012) Honaucins A-C, Potent inhibitors of inflammation and bacterial quorum sensing: Synthetic derivatives and structure-activity relationships. Chemistry \& Biology 19 (5):589-598. doi:http://dx.doi.org/10.1016/j.chembiol.2012.03.014

Dafforn KA, Lewis JA, Johnston EL (2011) Antifouling strategies: History and regulation, ecological impacts and mitigation. Mar Pollut Bull 62 (3):453-465. doi:http://dx.doi.org/10.1016/j.marpolbul.2011.01.012

Dang HY, Lovell CR (2016) Microbial surface colonization and biofilm development in marine environments. Microbiol Mol Biol R 80 (1):91-138. doi:http://dx.doi.org/10.1128/mmbr.00037-15

Desbois AP, Lebl T, Yan L, Smith VJ (2008) Isolation and structural characterisation of two antibacterial free fatty acids from the marine diatom, Phaeodactylum tricornutum. Appl Microbiol Biotechnol 81 (4):755-764. doi:http://dx.doi.org/10.1007/s00253-008-1714-9

Desbois AP, Mearns-Spragg A, Smith VJ (2009) A fatty acid from the diatom Phaeodactylum tricornutum is antibacterial against diverse bacteria including multi-resistant Staphylococcus aureus (MRSA). Mar Biotechnol 11 (1):45-52. doi:http://dx.doi.org/10.1007/s10126-0089118-5

Dobretsov S, Dahms HU, Qian PY (2006) Inhibition of biofouling by marine microorganisms and their metabolites. Biofouling 22 (1):43-54. doi:http://dx.doi.org/10.1080/08927010500504784

Doi Y, Ishibashi M, Nakamichi H, Kosaka T, Ishikawa T, Kobayashi J (1997) Luteophanol A, a new polyhydroxyl compound from symbiotic marine dinoflagellate Amphidinium sp. J Org Chem 62 (12):3820-3823. doi:http://dx.doi.org/10.1021/j09702731

Falaise C, François C, Travers M-A, Morga B, Haure J, Tremblay R, Turcotte F, Pasetto P, Gastineau R, Hardivillier Y, Leignel V, Mouget J-L (2016) Antimicrobial compounds from eukaryotic microalgae against human pathogens and diseases in aquaculture. Marine Drugs 14 (9):159-. doi:http://dx.doi.org/10.3390/md14090159 
Favre L, Ortalo-Magné A, Greff S, Pérez T, Thomas OP, Martin J-C, Culioli G (2017) Discrimination of four marine biofilm-forming bacteria by LC-MS metabolomics and influence of culture parameters. Journal of Proteome Research 16 (5):1962-1975. doi:10.1021/acs.jproteome.6b01027

Fernández-Alba AR, Hernando MD, Piedra L, Chisti Y (2002) Toxicity evaluation of single and mixed antifouling biocides measured with acute toxicity bioassays. Anal Chim Acta 456 (2):303-312. doi:http://dx.doi.org/10.1016/S0003-2670(02)00037-5

Fiehn O (2002) Metabolomics - the link between genotypes and phenotypes. Plant molecular biology 48 (1-2):155-171. doi:http://dx.doi.org/10.1023/A:1013713905833

Findlay JA, Patil AD (1984) Antibacterial constituents of the diatom Navicula delognei. J Nat Prod 47 (5):815-818. doi:http://dx.doi.org/10.1021/np50035a010

Fu E, Friedman L, Siegelman HW (1979) Mass-spectral identification and purification of phycoerythrobilin and phycocyanobilin. Biochemical Journal 179 (1):1-6. doi:10.1042/bj1790001

Fuentes-Grünewald C, Bayliss C, Fonlut F, Chapuli E (2016) Long-term dinoflagellate culture performance in a commercial photobioreactor: Amphidinium carterae case. Bioresource Technology 218:533-540. doi:http://dx.doi.org/10.1016/j.biortech.2016.06.128

Fusetani N (2004) Biofouling and antifouling. Nat Prod Rep 21 (1):94-104. doi:http://dx.doi.org/10.1039/B302231P

Fusetani N (2011) Antifouling marine natural products. Nat Prod Rep 28 (2):400-410. doi:http://dx.doi.org/10.1039/C0NP00034E

Gademann K (2007) Cyanobacterial natural products for the inhibition of biofilm formation and biofouling. CHIMIA International Journal for Chemistry 61 (6):373-377. doi:http://dx.doi.org/10.2533/chimia.2007.373

Gastineau R, Hardivillier Y, Leignel V, Tekaya N, Morançais M, Fleurence J, Davidovich N, Jacquette B, Gaudin P, Hellio C, Bourgougnon N, Mouget J-L (2012a) Greening effect on oysters and biological activities of the blue pigments produced by the diatom Haslea karadagensis (Naviculaceae). Aquaculture 368:61-67. doi:http://dx.doi.org/10.1016/j.aquaculture.2012.09.016

Gastineau R, Pouvreau J-B, Hellio C, Morançais M, Fleurence J, Gaudin P, Bourgougnon N, Mouget J-L (2012b) Biological activities of purified marennine, the blue pigment responsible for the greening of oysters. J Agr Food Chem 60 (14):3599-3605. doi:http://dx.doi.org/10.1021/jf205004x

Gordon BR, Leggat W (2010) Symbiodinium-invertebrate symbioses and the role of metabolomics. Marine Drugs 8 (10):2546-2568. doi:http://dx.doi.org/10.3390/md8102546

Guedes AC, Barbosa CR, Amaro HM, Pereira CI, Xavier Malcata F (2011) Microalgal and cyanobacterial cell extracts for use as natural antibacterial additives against food pathogens. 
International Journal of Food Science \& Technology 46 (4):862-870.

doi:http://dx.doi.org/10.1111/j.1365-2621.2011.02567.x

Hadfield MG (2011) Biofilms and marine invertebrate larvae: what bacteria produce that larvae use to choose settlement sites. Ann Rev Mar Sci 3:453-470. doi:http://dx.doi.org/10.1146/annurevmarine-120709-142753

Hay ME, Fenical W (1996) Chemical ecology and marine biodiversity: Insights and products from the sea. Oceanography 9:10-20. doi:http://dx.doi.org/10.5670/oceanog.1996.21

Holmström C, James S, Neilan BA, White DC, Kjelleber S (1998) Pseudoalteromonas tunicata sp. nov., a bacterium that produces antifouling agents. International Journal of Systematic and Evolutionary Microbiology 48 (4):1205-1212. doi:http://dx.doi.org/10.1099/00207713-48-4$\underline{1205}$

Hou Y, Braun DR, Michel CR, Klassen JL, Adnani N, Wyche TP, Bugni TS (2012) Microbial strain prioritization using metabolomics tools for the discovery of natural products. Analytical Chemistry 84 (10):4277-4283. doi:http://dx.doi.org/10.1021/ac202623g

Houdai T, Matsuoka S, Matsumori N, Murata M (2004) Membrane-permeabilizing activities of amphidinol 3, polyene-polyhydroxy antifungal from a marine dinoflagellate. Biochimica et Biophysica Acta (BBA) - Biomembranes 1667 (1):91-100. doi:https://doi.org/10.1016/j.bbamem.2004.09.002

Hu Y, Chen J, Hu G, Yu J, Zhu X, Lin Y, Chen S, Yuan J (2015) Statistical research on the bioactivity of new marine natural products discovered during the 28 years from 1985 to 2012. Marine drugs 13 (1):202-221. doi:http://dx.doi.org/10.3390/md13010202

Ingebrigtsen RA, Hansen E, Andersen JH, Eilertsen HC (2016) Light and temperature effects on bioactivity in diatoms. Journal of Applied Phycology 28:939-950. doi:http://dx.doi.org/10.1007/s10811-015-0631-4

Kobayashi J, Kubota T (2007) Bioactive macrolides and polyketides from marine dinoflagellates of the genus Amphidinium. J Nat Prod 70 (3):451-460. doi:http://dx.doi.org/10.1021/np0605844

Kong XY, Han XR, Gao M, Su RG, Wang K, Li XZ, Lu W (2016) Antialgal and antilarval activities of bioactive compounds extracted from the marine dinoflagellate Amphidinium carterae. Journal of Ocean University of China 15 (6):1014-1020. doi:http://dx.doi.org/10.1007/s11802-016-3013-x

Kubota T, Iwai T, Sakai K, Gonoi T, Kobayashi J (2014) Amphidinins C-F, Amphidinolide Q analogues from marine dinoflagellate Amphidinium sp. Organic letters 16 (21):5624-5627. doi:http://dx.doi.org/10.1021/o1502685z

Landoulsi J, Cooksey KE, Dupres V (2011) Review - Interactions between diatoms and stainless steel: Focus on biofouling and biocorrosion. Biofouling 27 (10):1105-1124. doi:http://dx.doi.org/10.1080/08927014.2011.629043 
Leao PN, Engene N, Antunes A, Gerwick WH, Vasconcelos V (2012) The chemical ecology of cyanobacteria. Nat Prod Rep 29 (3):372-391. doi:http://dx.doi.org/10.1039/C2NP00075J

Lee KWK, Periasamy S, Mukherjee M, Xie C, Kjelleberg S, Rice SA (2014) Biofilm development and enhanced stress resistance of a model, mixed-species community biofilm. Isme J 8 (4):894907. doi:http://dx.doi.org/10.1038/ismej.2013.194

Lejars M, Margaillan A, Bressy C (2012) Fouling release coatings: A nontoxic alternative to biocidal antifouling coatings. Chemical Reviews 112 (8):4347-4390. doi:http://dx.doi.org/10.1021/cr200350v

Lenoir S, Ten-Hage L, Turquet J, Quod J-P, Bernard C, Hennion M-C (2004) First evidence of palytoxin analogues from an Ostreopsis mascarensis (Dinophycea) benthic bloom in Southwestern Indian Ocean. Journal of Phycology 40 (6):1042-1051. doi:http://dx.doi.org/10.1111/j.1529-8817.2004.04016.x

Lopes VR, Fernández N, Martins RF, Vasconcelos V (2010) Primary screening of the bioactivity of brackishwater cyanobacteria: toxicity of crude extracts to Artemia salina larvae and Paracentrotus lividus embryos. Marine Drugs 8 (3):471-482. doi:http://dx.doi.org/10.3390/md803471

Martins R, Fernandez N, Beiras R, Vasconcelos V (2007) Toxicity assessment of crude and partially purified extracts of marine Synechocystis and Synechococcus cyanobacterial strains in marine invertebrates. Toxicon 50 (6):791-799. doi:http://dx.doi.org/10.1016/j.toxicon.2007.06.020

Mazur-Marzec H, Blaszczyk A, Felczykowska A, Hohlfeld N, Kobos J, Torunska-Sitarz A, Devi P, Montalvao S, D'Souza L, Tammela P, Mikosik A, Bloch S, Nejman-Falenczyk B, Wegrzyn G (2015) Baltic cyanobacteria - a source of biologically active compounds. Eur J Phycol 50 (3):343-360. doi:http://dx.doi.org/10.1080/09670262.2015.1062563

Montalvao S, Demirel Z, Devi P, Lombardi V, Hongisto V, Perala M, Hattara J, Imamoglu E, Tilvi SS, Turan G, Dalay MC, Tammela P (2016) Large-scale bioprospecting of cyanobacteria, micro- and macroalgae from the Aegean Sea. New Biotechnol 33 (3):399-406. doi:http://dx.doi.org/10.1016/j.nbt.2016.02.002

Mudimu O, Rybalka N, Bauersachs T, Born J, Friedl T, Schulz R (2014) Biotechnological screening of microalgal and cyanobacterial strains for biogas production and antibacterial and antifungal effects. Metabolites 4 (2):373-393. doi:http://dx.doi.org/10.3390/metabo4020373

Najdenski HM, Gigova LG, Iliev II, Pilarski PS, Lukavský J, Tsvetkova IV, Ninova MS, Kussovski VK (2013) Antibacterial and antifungal activities of selected microalgae and cyanobacteria. International Journal of Food Science \& Technology 48 (7):1533-1540. doi:http://dx.doi.org/10.1111/ijfs.12122

Neves RAF, Fernandes T, Santos LNd, Nascimento SM (2017) Toxicity of benthic dinoflagellates on grazing, behavior and survival of the brine shrimp Artemia salina. PLOS ONE 12 (4):e0175168. doi:https://doi.org/10.1371/journal.pone.0175168 
Nieva-Echevarría B, Goicoechea E, Manzanos MJ, Guillén MD (2014) A method based on 1H NMR spectral data useful to evaluate the hydrolysis level in complex lipid mixtures. Food Research International 66:379-387. doi:https://doi.org/10.1016/j.foodres.2014.09.031

Noaman NH, Fattah A, Khaleafa M, Zaky SH (2004) Factors affecting antimicrobial activity of Synechococcus leopoliensis. Microbiological Research 159 (4):395-402. doi:http://dx.doi.org/10.1016/j.micres.2004.09.001

Othmani A, Bouzidi N, Viano Y, Alliche Z, Seridi H, Blache Y, Hattab M, Briand J-F, Culioli G (2014) Anti-microfouling properties of compounds isolated from several Mediterranean Dictyota spp. Journal of Applied Phycology 26 (3):1573-1584. doi:http://dx.doi.org/10.1007/s10811-013-0185-2

Othmani A, Briand J-F, Ayé M, Molmeret M, Culioli G (2016a) Surface metabolites of the brown alga Taonia atomaria have the ability to regulate epibiosis. Biofouling 32 (7):801-813. doi:http://dx.doi.org/10.1080/08927014.2016.1198954

Othmani A, Bunet R, Bonnefont J-L, Briand J-F, Culioli G (2016b) Settlement inhibition of marine biofilm bacteria and barnacle larvae by compounds isolated from the Mediterranean brown alga Taonia atomaria. Journal of Applied Phycology 28 (3):1975-1986. doi:http://dx.doi.org/10.1007/s10811-015-0668-4

Paul VJ, Thacker RW, Banks K, Golubic S (2005) Benthic cyanobacterial bloom impacts the reefs of South Florida (Broward County, USA). Coral Reefs 24 (4):693-697. doi:http://dx.doi.org/10.1007/s00338-005-0061-x

Pérez M, Falqué E, Domínguez H (2016) Antimicrobial action of compounds from marine seaweed. Marine Drugs 14 (3):52. doi:http://dx.doi.org/10.3390/md14030052

Pulz O, Gross W (2004) Valuable products from biotechnology of microalgae. Appl Microbiol Biotechnol 65 (6):635-648. doi:http://dx.doi.org/10.1007/s00253-004-1647-x

Qian PY, Lau SCK, Dahms HU, Dobretsov S, Harder T (2007) Marine biofilms as mediators of colonization by marine macroorganisms: Implications for antifouling and aquaculture. Mar Biotechnol 9 (4):399-410. doi:http://dx.doi.org/10.1007/s10126-007-9001-9

Qian PY, Li ZR, Xu Y, Li YX, Fusetani N (2015) Mini-review: Marine natural products and their synthetic analogs as antifouling compounds: 2009-2014. Biofouling 31 (1):101-122. doi:http://dx.doi.org/10.1080/08927014.2014.997226

Qian PY, Xu Y, Fusetani N (2010) Natural products as antifouling compounds: Recent progress and future perspectives. Biofouling 26 (2):223-234. doi:http://dx.doi.org/10.1080/08927010903470815

Raniello R, Iannicelli MM, Nappo M, Avila C, Zupo V (2007) Production of Cocconeis neothumensis (Bacillariophyceae) biomass in batch cultures and bioreactors for biotechnological applications: light and nutrient requirements. Journal of Applied Phycology 19 (4):383-391. doi:http://dx.doi.org/10.1007/s10811-006-9145-4 
Rittschof D, Clare AS, Gerhart DJ, Mary SA, Bonaventura J (1992) Barnacle in vitro assays for biologically active substances: Toxicity and settlement inhibition assays using mass cultured Balanus amphitrite amphitrite darwin. Biofouling 6 (2):115-122. doi:http://dx.doi.org/10.1080/08927019209386217

Saeed AF, Awan SA, Ling SM, Wang RZ, Wang S (2017) Domoic acid: Attributes, exposure risks, innovative detection techniques and therapeutics. Algal Research-Biomass Biofuels and Bioproducts 24:97-110. doi:http://dx.doi.org/10.1016/j.algal.2017.02.007

Salta M, Wharton JA, Blache Y, Stokes KR, Briand J-F (2013) Marine biofilms on artificial surfaces: structure and dynamics. Environmental Microbiology 15 (11):2879-2893

Sanchez-Saavedra MD, Licea-Navarro A, Bernaldez-Sarabia J (2010) Evaluation of the antibacterial activity of different species of phytoplankton. Revista De Biologia Marina Y Oceanografia 45 (3):531-536. doi:http://dx.doi.org/10.4067/S0718-19572010000300019

Scardino AJ, de Nys R (2011) Mini review: Biomimetic models and bioinspired surfaces for fouling control. Biofouling 27 (1):73-86. doi:http://dx.doi.org/10.1080/08927014.2010.536837

Schultz MP, Bendick JA, Holm ER, Hertel WM (2011) Economic impact of biofouling on a naval surface ship. Biofouling 27 (1):87-98. doi:http://dx.doi.org/10.1080/08927014.2010.542809

Singh S, Verma SK (2012) Application of direct analysis in real time mass spectrometry (DART-MS) for identification of an epiphytic cyanobacterium, Nostoc sp. Analytical Letters 45 (17):25622568. doi:10.1080/00032719.2012.694940

Smida DB, Lundholm N, Kooistra WHCF, Sahraoui I, Ruggiero MV, Kotaki Y, Ellegaard M, Lambert C, Mabrouk HH, Hlaili AS (2014) Morphology and molecular phylogeny of Nitzschia bizertensis sp. nov.-A new domoic acid-producer. Harmful Algae 32:49-63. doi:http://dx.doi.org/10.1016/j.hal.2013.12.004

Smith CA, Want EJ, O'Maille G, Abagyan R, Siuzdak G (2006) XCMS: Processing mass spectrometry data for metabolite profiling using nonlinear peak alignment, matching, and identification. Analytical Chemistry 78 (3):779-787. doi:10.1021/ac051437y

Suriyanti SNP, Usup G (2015) First report of the toxigenic Nitzschia navis-varingica (Bacillariophyceae) isolated from Tebrau Straits, Johor, Malaysia. Toxicon 108:257-263. doi:http://dx.doi.org/10.1016/j.toxicon.2015.10.017

Taylor MS, Stahl-Timmins W, Redshaw CH, Osborne NJ (2014) Toxic alkaloids in Lyngbya majuscula and related tropical marine cyanobacteria. Harmful Algae 31 (0):1-8. doi:http://dx.doi.org/10.1016/j.hal.2013.09.003

Ten-Hage Lc, Robillot C, Turquet J, Le Gall F, Le Caer J-P, Bultel V, Guyot M, Molgó J (2002) Effects of toxic extracts and purified borbotoxins from Prorocentrum borbonicum (Dinophyceae) on vertebrate neuromuscular junctions. Toxicon 40 (2):137-148. doi:http://dx.doi.org/10.1016/S0041-0101(01)00200-8 
Van Wagoner RM, Satake M, Wright JLC (2014) Polyketide biosynthesis in dinoftagellates: What makes it different? Nat Prod Rep 31 (9):1101-1137. doi:http://dx.doi.org/10.1039/c4np00016a Viles HA, Spencer T, Teleki K, Cox C (2000) Observations on 16 years of microfloral recolonization data from limestone surfaces, Aldabra Atoll, Indian Ocean: implications for biological weathering. Earth Surface Processes and Landforms 25 (12):1355-1370. doi:http://dx.doi.org/10.1002/1096-9837(200011)25:12<1355::AID-ESP143>3.0.CO;2-T

Volk R-B, Furkert FH (2006) Antialgal, antibacterial and antifungal activity of two metabolites produced and excreted by cyanobacteria during growth. Microbiological Research 161 (2):180-186. doi:https://doi.org/10.1016/j.micres.2005.08.005

Washida K, Koyama T, Yamada K, Kita M, Uemura D (2006) Karatungiols A and B, two novel antimicrobial polyol compounds, from the symbiotic marine dinoflagellate Amphidinium sp. Tetrahedron Lett 47 (15):2521-2525. doi:http://dx.doi.org/10.1016/j.tetlet.2006.02.045

Wichard T, Poulet AS, Halsband-Lenk C, Albaina A, Harris R, Liu D, Pohnert G (2005) Survey of the chemical defence potential of diatoms: Screening of fifty species for $\alpha, \beta, \gamma, \delta$-unsaturated aldehydes. Journal of Chemical Ecology 31 (4):949-958. doi:http://dx.doi.org/10.1007/s10886-005-3615-z

Xu L, Weathers PJ, Xiong X-R, Liu C-Z (2009) Microalgal bioreactors: Challenges and opportunities. Engineering in Life Sciences 9 (3):178-189. doi:http://dx.doi.org/10.1002/elsc.200800111

Yebra DM, Kiil S, Dam-Johansen K (2004) Antifouling technology - past, present and future steps towards efficient and environmentally friendly antifouling coatings. Prog Org Coat 50 (2):75104. doi:http://dx.doi.org/10.1016/j.porgcoat.2003.06.001

Zea Obando C, Linossier I, Kervarec N, Zubia M, Turquet J, Faÿ F, Rehel K (2016) Rapid identification of osmolytes in tropical microalgae and cyanobacteria by ${ }^{1} \mathrm{H}$ HR-MAS NMR spectroscopy. Talanta 153:372-380. doi:http://dx.doi.org/10.1016/j.talanta.2016.02.024 
855 Figure 1: PCA score plot obtained from LC-MS profiles of $46 \mathrm{MeOH}$ fractions of tropical microalgae.

856 Symbols were sized by bioactivity (i.e. $1 / \mathrm{EC}_{50}$ ). Ellipses were drawn manually according to taxa 857 clustering (the eukaryotic strains that clustered with Cyanobacteria were not included).

858

859 Table 1: Origin, identification (i.e. names accepted according to Guiry and Guiry 2017), culture media 860 and identification number of the 50 tropical microalgae used in this study.

861 Table 2: Anti-adhesion activity $\left(\mathrm{EC}_{50}\right.$, mean $\left.\pm \mathrm{SD}\right)$ of microalgal fractions on the three fouling bacteria 862 (TC8: Pseudoalteromonas lipolytica, TC5: Polaribacter sp. and TC11: Shewanella sp.). Only data for $863 \mathrm{MeOH}$ fractions showing activity against at least one bacterium were given. A grey scale has been 864 applied to ease the visualization of the results. $* n=2$. **Published in Othmani et al. (Othmani et al. 865 2016b), mentioned here as a reference.

866 Table 3: Growth inhibition $\left(\mathrm{IC}_{50}\right)$, mortality $\left(\mathrm{LC}_{50}\right)$ and selectivity index $\left(\mathrm{SI}=\mathrm{LC}_{50} / \mathrm{EC}_{50}\right)$ of tropical 867 microalgae $\mathrm{MeOH}$ fractions on the three biofilm-forming bacteria (TC8: Pseudoalteromonas lipolytica, 868 TC5: Polaribacter sp. and TC11: Shewanella sp.). Two distinct grey scales (one for $\mathrm{IC}_{50}$ and $\mathrm{LC}_{50}$ and 869 one for SI) have been applied to ease the visualization of the results. *Published in Othmani et al. 870 (Othmani et al. 2016b), mentioned here as a reference.

871 Table 4: Anti-settlement activity $\left(\mathrm{EC}_{50}\right)$ and mortality $\left(\mathrm{LC}_{50}\right)$ of the $\mathrm{MeOH}$ fraction of three tropical 872 microalgae against $A$. amphitrite nauplii and cyprids (expressed as mean $\pm \mathrm{SD}$ ). 
Table 1: Origin, identification (i.e. names accepted according to Guiry and Guiry 2017), culture media and identification number of the 50 tropical microalgae used in this study.

\begin{tabular}{|c|c|c|c|c|c|c|}
\hline Phyla & Family & Genus & Species & $\begin{array}{l}\text { Collection } \\
\text { Site }\end{array}$ & $\begin{array}{c}\text { Cultur } \\
\text { e } \\
\text { Media }^{a}\end{array}$ & ID $^{\mathbf{b}}$ \\
\hline Haptophyta & Pavlovaceae & Pavlova & sp. & Glorioso & $\mathrm{F} / 2$ & P-69 \\
\hline \multirow{3}{*}{ Cryptophyta } & \multirow{3}{*}{$\mathrm{ND}^{\mathrm{c}}$} & Cryptophyta & sp. & Glorioso & $\mathrm{F} / 2$ & P-67 \\
\hline & & Cryptophyta & sp. & Glorioso & $\mathrm{F} / 2$ & P-68 \\
\hline & & Cryptophyta & sp. & Glorioso & $F / 2$ & P-70 \\
\hline \multirow{19}{*}{$\begin{array}{c}\text { Miozoa } \\
\text { (Dinoflagellates) }\end{array}$} & \multirow{11}{*}{ Gymnodiniaceae } & Amphidinium & carterae & Reunion & $\mathrm{F} / 2$ & P-38 \\
\hline & & Amphidinium & massartii & Mauritius & $\mathrm{F} / 2$ & $P-41$ \\
\hline & & Amphidinium & massartii & Europa & $\mathrm{F} / 2$ & P-42 \\
\hline & & Amphidinium & gibbosum & Europa & $\mathrm{F} / 2$ & $P-43$ \\
\hline & & Amphidinium & massartii & Glorioso & $\mathrm{F} / 2$ & $P-44$ \\
\hline & & Amphidinium & carterae & Glorioso & $\mathrm{F} / 2$ & P-45 \\
\hline & & Amphidinium & carterae & Glorioso & $\mathrm{F} / 2$ & $P-46$ \\
\hline & & Amphidinium & carterae & Madagascar & $\mathrm{F} / 2$ & P-59 \\
\hline & & Amphidinium & carterae & Madagascar & $\mathrm{F} / 2$ & P-60 \\
\hline & & Amphidinium & carterae & Madagascar & $\mathrm{F} / 2$ & P-63 \\
\hline & & Amphidinium & massartii & Reunion & $\mathrm{F} / 2$ & P-80 \\
\hline & \multirow{3}{*}{ Prorocentraceae } & Prorocentrum & lima & Reunion & $\mathrm{F} / 2$ & P-04 \\
\hline & & Prorocentrum & $\operatorname{lima}$ & Reunion & $\mathrm{F} / 2$ & P-08 \\
\hline & & Prorocentrum & $\operatorname{lima}$ & Reunion & $F / 2$ & $\mathbf{P}-\mathbf{3 7}$ \\
\hline & \multirow{5}{*}{ Suessiaceae } & Symbiodinium & sp. (Clade F) & Reunion & $\mathrm{F} / 2$ & P-72 \\
\hline & & Symbiodinium & sp. (Clade B) & Reunion & $\mathrm{F} / 2$ & P-73 \\
\hline & & Symbiodinium & sp. & Reunion & $\mathrm{F} / 2$ & P-76 \\
\hline & & Symbiodinium & sp. (Clade D) & Reunion & $\mathrm{F} / 2$ & P-78 \\
\hline & & Symbiodinium & sp. (Y6-1) & Reunion & $\mathrm{F} / 2$ & P-79 \\
\hline \multirow{4}{*}{$\begin{array}{l}\text { Bacillariophyta } \\
\text { (Diatoms) }\end{array}$} & \multirow{2}{*}{ Naviculaceae } & Navicula & mollis & Reunion & $\mathrm{F} / 2+\mathrm{Si}$ & P-91* \\
\hline & & Navicula & sp. & Reunion & $\mathrm{F} / 2+\mathrm{Si}$ & P-92* \\
\hline & \multirow{2}{*}{ Bacillariaceae } & Nitzschia & sp. & Reunion & $\mathrm{F} / 2+\mathrm{Si}$ & P-89* \\
\hline & & Psammodictyon & sp. aff. constrictum & Reunion & $\mathrm{F} / 2+\mathrm{Si}$ & P-90* \\
\hline \multirow{21}{*}{ Cyanobacteria } & Merismopediaceae & Synechocystis & sp. & Madagascar & $\mathrm{F} / 2$ & C-02 \\
\hline & Chroococcaceae & Gloeocapsopsis & sp. & Glorioso & BG11 & C-61* \\
\hline & Cyanothecaceae & Cyanothece & sp. & Glorioso & BG11 & C-58* \\
\hline & \multirow{4}{*}{ ND } & ND & sp. & Glorioso & BG11 & C-59* \\
\hline & & LPP-group & sp. (LPP1) & Mayotte & BG11 & C-09* \\
\hline & & LPP-group & sp. (LPP1) & Mayotte & BG11 & C-12* \\
\hline & & LPP-group & sp. (LPP1) & Mayotte & BG11 & C-14* \\
\hline & \multirow{2}{*}{ Coleofasciculaceae } & Roseofilum & sp. & Reunion & BG11 & $\mathrm{C}-07 *$ \\
\hline & & Roseofilum & sp. & Reunion & BG11 & C-32* \\
\hline & \multirow{5}{*}{ Leptolyngbyaceae } & Leptolyngbya & sp. & Mayotte & BG11 & C-10* \\
\hline & & Leptolyngbya & sp. & Mayotte & Z8 & C-13* \\
\hline & & Leptolyngbya & sp. (RS01) & Mayotte & BG11 & C-16* \\
\hline & & Leptolyngbya & sp. & Reunion & BG11 & C-18* \\
\hline & & Leptolyngbya & sp. & Reunion & BG11 & C-23* \\
\hline & \multirow{2}{*}{ Spirulinaceae } & Spirulina & subsalsa & Reunion & BG11 & C-17* \\
\hline & & Spirulina & sp. & Reunion & BG11 & C-27* \\
\hline & \multirow{3}{*}{ Pseudanabaenaceae } & Pseudoanabaena & sp. & Reunion & BG11 & $\mathrm{C}-24 *$ \\
\hline & & Pseudoanabaena & sp. & Reunion & BG11 & C-30* \\
\hline & & Limnothrix & sp. & Reunion & BG11 & C-33* \\
\hline & \multirow{2}{*}{ Synechococcaceae } & Synechococcus & elongatus & Madagascar & $\mathrm{F} / 2$ & C-01 \\
\hline & & Synechococcus & elongatus & Glorioso & BG11 & C-60* \\
\hline \multirow{2}{*}{ Rhodophyta } & Porphyridiaceae & Porphyridium & sp. & Glorioso & BG11 & C-64* \\
\hline & Stylonemataceae & Choodactylon & sp. aff. ornatum & Mayotte & BG11 & C-03* \\
\hline
\end{tabular}

${ }^{\mathrm{a} C}$ Culture media: F/2 and F/2+Si: Guillard's medium without or with silicate (Guillard 1975); BG11: Blue Green Medium (Stanier et al. 1971); Z8 medium (Kotai 1972); ' ID: Phytobank identification number; ${ }^{\mathrm{c} N D}$ : not determined; *strains isolated from biofilms or growing while isolating biofilms 
Table 2: Anti-adhesion activity $\left(\mathrm{EC}_{50}\right.$, mean $\left.\pm \mathrm{SD}\right)$ of microalgal fractions on the three fouling bacteria (TC8: Pseudoalteromonas lipolytica, TC5: Polaribacter sp. and TC11: Shewanella sp.). Only data for $\mathrm{MeOH}$ fractions showing activity against at least one bacterium were given. A colour scale has been applied to ease the visualization of the results (red: <10; orange: 11-30; yellow: 31-50; green: 51-99; blue: $>100) . * n=2$. **Published in Othmani et al. [29], mentioned here as a reference.

\begin{tabular}{|c|c|c|c|c|}
\hline \multirow{2}{*}{$\begin{array}{l}\text { Phytobank } \\
\text { ID }\end{array}$} & \multirow{2}{*}{ Microalgae } & \multicolumn{3}{|c|}{$\mathrm{EC}_{50}(\mu \mathrm{g} / \mathrm{mL})$} \\
\hline & & TC8 & TC11 & TC5 \\
\hline P-69 & Pavlova sp. & $15 \pm 1.1$ & 33 & $27 \pm 5.9$ \\
\hline P-68 & Cryptophyta sp. & $60 \pm 17$ & 7.0 & $24 \pm 12$ \\
\hline P-70 & Cryptophyta sp. & $>100$ & na & $13 \pm 2.4$ \\
\hline P-38 & Amphidinium carterae & $22 \pm 11$ & 5.8 & $20 \pm 14$ \\
\hline P-41 & Amphidinium massartii & $>100$ & 16 & $18 \pm 13$ \\
\hline P-43 & Amphidinium gibbosum & $10 \pm 2.3$ & 1.0 & $6.3 \pm 3.2$ \\
\hline P-44 & Amphidinium massartii & $7.1 \pm 5.8$ & 2.3 & $12 \pm 7.6$ \\
\hline P-45 & Amphidinium carterae & $9.8 \pm 1.0$ & 15 & $14 \pm 5.5$ \\
\hline P-46 & Amphidinium carterae & $15 \pm 0.2$ & 19 & $>100$ \\
\hline P-59 & Amphidinium carterae & $15 \pm 2.4$ & 29 & $15 \pm 3.0$ \\
\hline P-60 & Amphidinium carterae & $24 \pm 15$ & 4.5 & $28 \pm 9.1$ \\
\hline P-63 & Amphidinium carterae & $13 \pm 4.7$ & 2.6 & $14 \pm 8.6$ \\
\hline P-08 & Prorocentrum lima & $13 \pm 2.7$ & na & 13 \\
\hline P-37 & Prorocentrum lima & $>100$ & na & $15 \pm 9.1$ \\
\hline P-76 & Symbiodinium sp. & $>100$ & 8 & $17 \pm 6.9$ \\
\hline P-78 & Symbiodinium sp. & $9.6 \pm 4.7$ & 6.9 & $9.3 \pm 7.7$ \\
\hline P-91 & Navicula mollis & $28 \pm 3.3$ & $22 \pm 18$ & 24 \\
\hline P-92 & Navicula sp. & $75 \pm 14$ & $57 \pm 18$ & 15 \\
\hline P-89 & Nitzschia sp. & $33 \pm 22$ & $47 \pm 9.0$ & 13 \\
\hline P-90 & $\begin{array}{l}\text { Psammodictyon cf. } \\
\text { constrictum }\end{array}$ & $13 \pm 2.1$ & $42 \pm 19$ & 21 \\
\hline C-58 & cf. Cyanothece sp. & $63 \pm 18$ & $83 \pm 26$ & na \\
\hline C-59 & Cyanobacteria sp. & 10 & 68 & na \\
\hline C-61 & Cyanobacteria sp. & 25 & 50 & na \\
\hline C-32 & Roseofilum sp. & $47 \pm 16$ & 59 & 43 \\
\hline C-18 & cf. Leptolyngbya sp. & na & $>100$ & na \\
\hline C-27 & Spirulina sp. & $>100$ & na & na \\
\hline C-30 & Pseudoanabaena sp. & $41 \pm 20$ & 42 & na \\
\hline C-60 & Synechococcus elongatus & $79 \pm 9$ & 57 & 48 \\
\hline \multirow[t]{2}{*}{ C-64 } & cf Porphyridium sp. & $31 \pm 20$ & 49 & na \\
\hline & TBTO $* *\left(\times 10^{-3}\right)$ & $4.2 \pm 3.0$ & $1.2 \pm 0.60$ & $14 \pm 7.2$ \\
\hline
\end{tabular}

na: not analyzed (i.e. insufficient material); >100: no anti-adhesion activity was observed 
Table 3: Growth inhibition ( $\left.\mathrm{IC}_{50}\right)$, mortality $\left(\mathrm{LC}_{50}\right)$ and selectivity index $\left(\mathrm{SI}=\mathrm{LC}_{50} / \mathrm{EC}_{50}\right)$ of tropical microalgae $\mathrm{MeOH}$ fractions on the three biofilm-forming bacteria (TC8: Pseudoalteromonas lipolytica, TC5: Polaribacter sp. and TC11: Shewanella sp.). Two distinct colour scales (one for $\mathrm{IC}_{50}$ and $\mathrm{LC}_{50}$; red: <29; orange: 30-49; yellow: 50-99; green: >100 and one for SI: green: <5; yellow: 6-10; orange: 11-15; red: >15) have been applied to ease the visualization of the results. *Published in Othmani et al. [29], mentioned here as a reference.

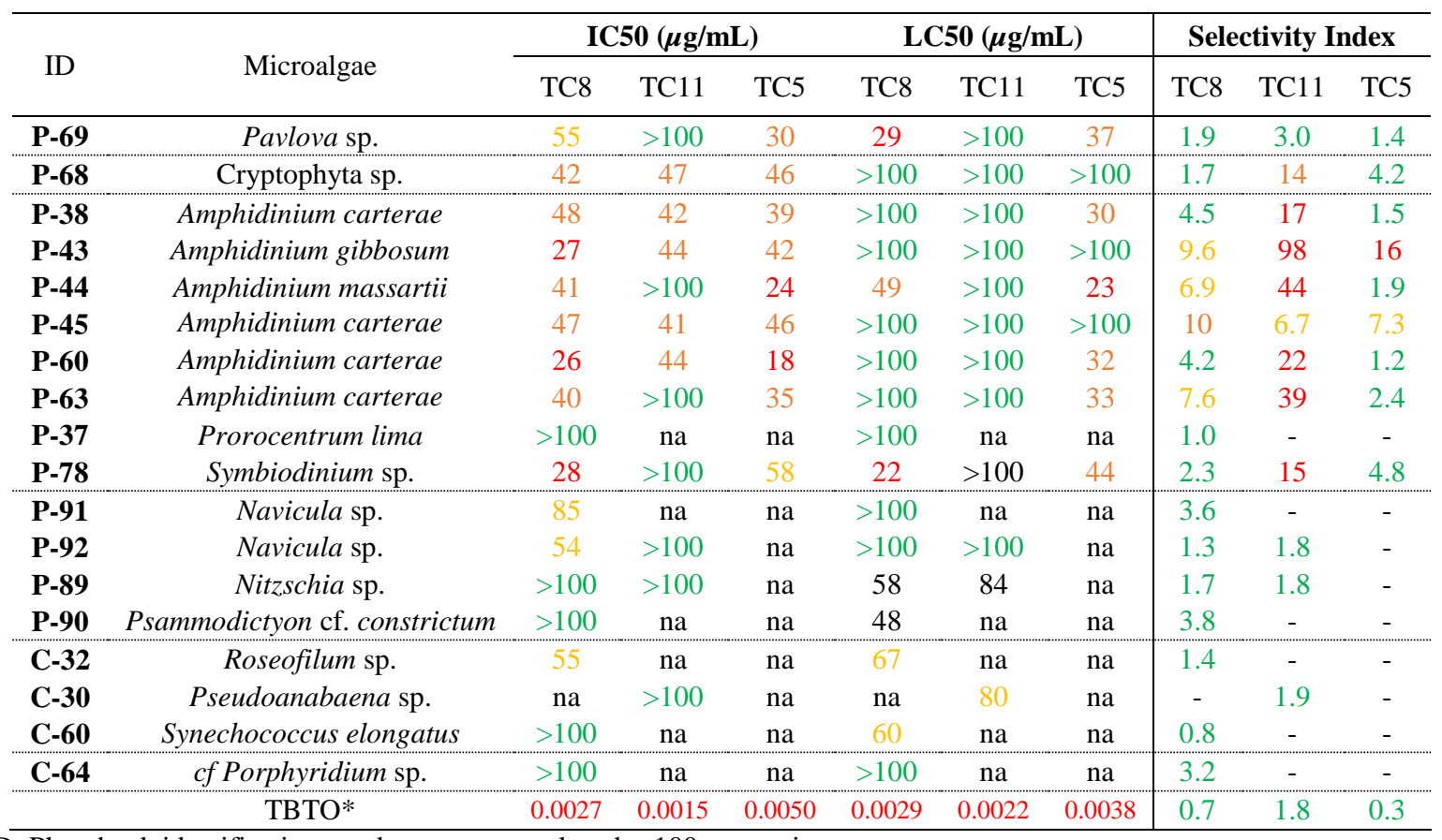

ID: Phytobank identification number; na: not analyzed; >100: not active 
Table 4: Anti-settlement activity $\left(\mathrm{EC}_{50}\right)$ and mortality $\left(\mathrm{LC}_{50}\right)$ of the $\mathrm{MeOH}$ fraction of three tropical microalgae against $A$. amphitrite nauplii and cyprids (expressed as mean $\pm \mathrm{SD}$ ).

\begin{tabular}{cccc}
\hline \multirow{2}{*}{ ID } & $\mathrm{EC}_{50}(\mu \mathrm{g} / \mathrm{mL})$ & \multicolumn{2}{c}{$24 \mathrm{~h}-\mathrm{LC}_{50}(\mu \mathrm{g} / \mathrm{mL})$} \\
\cline { 3 - 4 } & & Stage V/VI nauplii & Cyprids \\
\hline P-91 & 7.5 & $>100$ & $>100$ \\
P-43 & $31 \pm 3$ & $>150$ & $89 \pm 5$ \\
P-60 & $45 \pm 4$ & $>150$ & $46 \pm 6$ \\
\hline TBTO* & $(4.5 \pm 0.3) \times 10^{-5}$ & $(11 \pm 0.2) \times 10^{-5}$ & $(14 \pm 1) \times 10^{-5}$ \\
\hline
\end{tabular}

$*$ published in Othmani et al. 2016b, mentioned here as a reference 


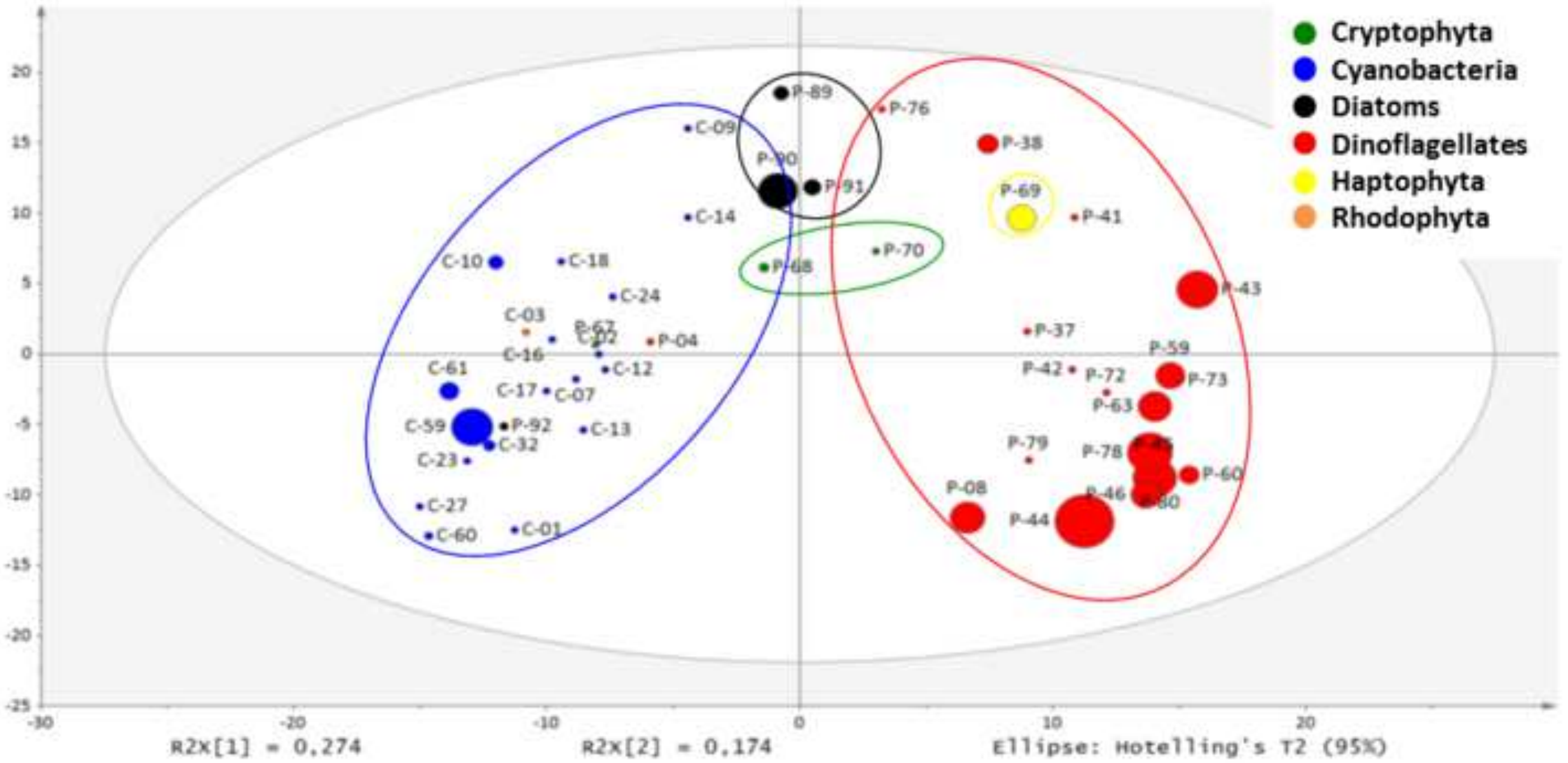

11 ipse: Hotelling's T2 (95\%) 


\section{Click here to access/download \\ Supplementary Material Supp Figures V2.docx}

